\title{
ФОРМУВАННЯ ЕЛЕМЕНТІВ КУЛЬТУРИ ДЕМОКРАТІЇ МОЛОДШИХ ШКОЛЯРІВ У ПРОЦЕСІ ПРОВЕДЕННЯ РАНКОВИХ ЗУСТРІЧЕЙ
}

\begin{abstract}
Анотація. В статті обтрунтовано важливість питання формування в учнів культури демократії, яка $е$ однією з важливих ознак приведення українського суспільства до стандартів європейських держав. Розкрита важливість пошуків інноваційних підходів до вироблення в учнів ключових компетентностей культури демократії. Охарактеризовані компетентності, що складають основу Рамки компетентностей культури демократії та міжкультурного діалогу. Наводяться приклади проведення ранкових зустрічей під час яких формуються у молодших школярів головні компетенції культури демократії. Проведено анкетування вчителів початкового навчання, які безпосередньо втілюють в практику формування культури демократії на ранкових зустрічах в 1-4 класах та проаналізовано слабкі і сильні сторони тематичних ранкових зустрічей даної тематики.
\end{abstract}

Ключові слова: НУШ, ключові компетенції, ранкова зустріч, групові вправи, Рамка компетентностей культури демократії.

Streletska Nataliia, Chebotar Yuliia

T.H. Shevchenko National University "Chernihiv Colehium"

\section{FORMATION OF CULTURAL ELEMENTS OF DEMOCRACY OF YOUNGER PUPILS IN THE PROCESS OF MORNING MEETINGS}

Summary. One of the innovative forms of learning that creates opportunities for solving problems is an integral part of the modern educational process in primary school - a morning meeting. The article substantiates the importance of the formation of a culture of democracy of schoolchildren, which is one of the important signs of bringing Ukrainian society to the standards of European states. The importance of searching for innovative approaches to developing students' key competencies in the culture of democracy is revealed. The competencies that form the basis of the Competence Framework for the Culture of Democracy and Intercultural Dialogue are described. Examples are given of holding morning meetings during which the main competencies of the culture of democracy are formed in junior schoolchildren. A survey of primary school teachers who directly implement the practice of forming a culture of democracy in the morning meetings in grades 1-4 and analyzed the strengths and weaknesses of thematic morning meetings on this topic. Nowadays, the problem of developing a culture of democracy for schoolchildren becomes especially relevant, because there is a change in values, children show signs of competition, put themselves first. To create a democratic society in which people respect the opinion of others, where moral qualities are valued, it is necessary to instill in children such qualities as friendliness, mercy, tolerance and others. The formation of elements of the culture of democracy of primary schoolchildren is a necessary condition for the introduction of educational reform in NUS. Morning meetings are a new active pedagogical technology that allows children to participate in group discussions, and teachers - to model and actively develop children's skills and abilities of effective communication. Regarding the development of competencies of elements of democratic culture, these skills contribute to the development of a sense of community and a wider range of positive manifestations of such qualities as better attitude to school and learning, greater trust and respect for teachers, higher motivation to learn, deeper self-esteem, increased concern for others, a fuller understanding of democratic values, a wider practice of conflict resolution.

Keywords: NUS, key competencies, morning meeting, culture of democracy, Competence framework

$\Pi$ остановка проблеми. В наш час проблема розвитку культури демократії школярів набуває особливої актуальності, адже відбувається зміна ціннісних орієнтирів, діти виявляють риси конкуренції, ставлять себе на перше місце. Для створення демократичного суспільства, в якому люди поважають думку інших, де цінуються моральні якості, потрібно виховувати в дітей такі якості як дружелюбність, милосердя, толерантність та інші.

Нова українська школа зорієнтована на формування ключових компетентностей молодших школярів, а саме навчає впевнено і щасливо почувати себе в нестабільному світі, самостійно вирішувати життєві проблеми, сприяє усвідомленню демократичних цінностей суспільства.

Все це зумовлюе пошук творчого вчителя нових інноващійних підходів, технологій та форм навчання, які б моделювали життеві природні умови для здійснення міжособистісної взаємодії учнів, розвитку їх ініціативності, взаємодопомоги, емоційного інтелекту, елементів культури демократії.

Однією 3 інноваційних форм навчання, що створюе можливості для вирішення указаних завдань є складова частина сучасного освітнього процесу в початковій школі - ранкова зустріч.

Аналіз останніх досліджень і публікацій. Організацію виховного процесу на ранковій зустрічі досліджували видатні педагоги К. Бобко, Н. Барабанова, Л. Булахова, Г. Жук, А. Китиченко, Н. Коцур, С. Корнієнко, Л. Падалка. Проблема міжособистісних відносин дітей з однолітками досить докладно вивчали Г. Костюк, Г. Глуменюк, В. Абраменкова, I. Дубровіна, М. Лисина, В. Мухина.

Формуванню демократичних цінностей в молодших школярів приділяли увагу у своїх працях науковці та педагоги I. Беха, В. Акимова, В. Гуріна, С. Максименка, Л. Божовича, О. Киричука, 
Г. Костюка, В. Котирла, Г. Костюка, В. Котирла, Б. Кобзара, М. Красовицького, Ю. Приходька, Ю. Руденка, О. Роговець.

Проте, недостатньо на сьогоднішній день розроблено методичних підходів щодо фрормування елементів культури демократії молодших школярів під час ранкових зустрічей.

Мета статті. Головною метою цієї роботи $є$ розкриття потенціалу ранкових зустрічей у формуванні елементів культури демократії

За останні роки Рада Свропи головну увагу приділяе освіті щодо сприяння і захисту прав людини, демократії та ін. На переконання вчених, набуття здатності брати активну участь у демократичних процесах починається ще у ранньому дитинстві і триває впродовж усього життя, а тому освітні установи мають брати активну участь у цьому та бути місцем демократичної освіти.

Департаментом освіти Ради Свропи (С’юp Берган, Віллано Кіріазі, Крістофер Рейнольдс, Мірей Вендлін, Клодін Мартен-Оствальд) та міжнародними експертами з питань освіти (Мартин Барретт, Луіза де Бівар Блек, Міхаель Бірам, Ярослав Фалтин, Ларс Гудмундсон, Гіліл'є вант Ланд, Клаудіа Ленц, Паскаль Момпуа-Гайяр, Мiліса Поповіч, Калін Рус, Сальвадор Сала, Наталія Воскресенская, Павел Згага) було розроблено Рамку компетентностей для культури демократії. Це документ, у якому запропоновано «системний підхід до організації процесу формування й оцінювання компетентностей для культури демократії та їхнього впровадження в освітні системи» від дошкільного навчання до вищої школи [1, с. 11].
Основою Рамки є модель компетентностей, яку мають засвоювати учні для ефективної участі в культурі демократії та мирного співжиття 3 іншими у культурно багатоманітних демократичних суспільствах. Рамка містить дескриптори всіх компетентностей різних моделей [2].

Ранкова зустріч - це запланований, структурований збір. Учителі присвячують 20-25 хвилин кожного дня вранці для того, щоб створити позитивну атмосореру на весь період перебування дітей у школі. Ранкова зустріч відбувається в класній кімнаті на килимі, кожен займає зручне для себе положення, що сприяе більш вільному відкритому спілкуванню. Рекомендовану послідовність компонентів - вітання, обмін інформаціею, групове заняття, щоденні новини - можна змінити відповідно до потреб кожного класу.

Вправи, які використовуються під час проведення ранкових зустрічей, допомагають учням знайти спільну мову зі своїми однолітками, навчають співпрацювати, поважати інших та їхні думки. На думку вчених, позитивна атмосфера створюеться за рахунок:

- довіри;

- відчуття приналежності до спільноти;

- участі в прийнятті рішень;

- доброти та заохочення з боку ровесників;

- вільного від критики ставлення вчителя, вихователя;

- очікування конкретних результатів;

- справедливості та неупередженості.

Позитивна атмосорера створюеться завдяки використанню:

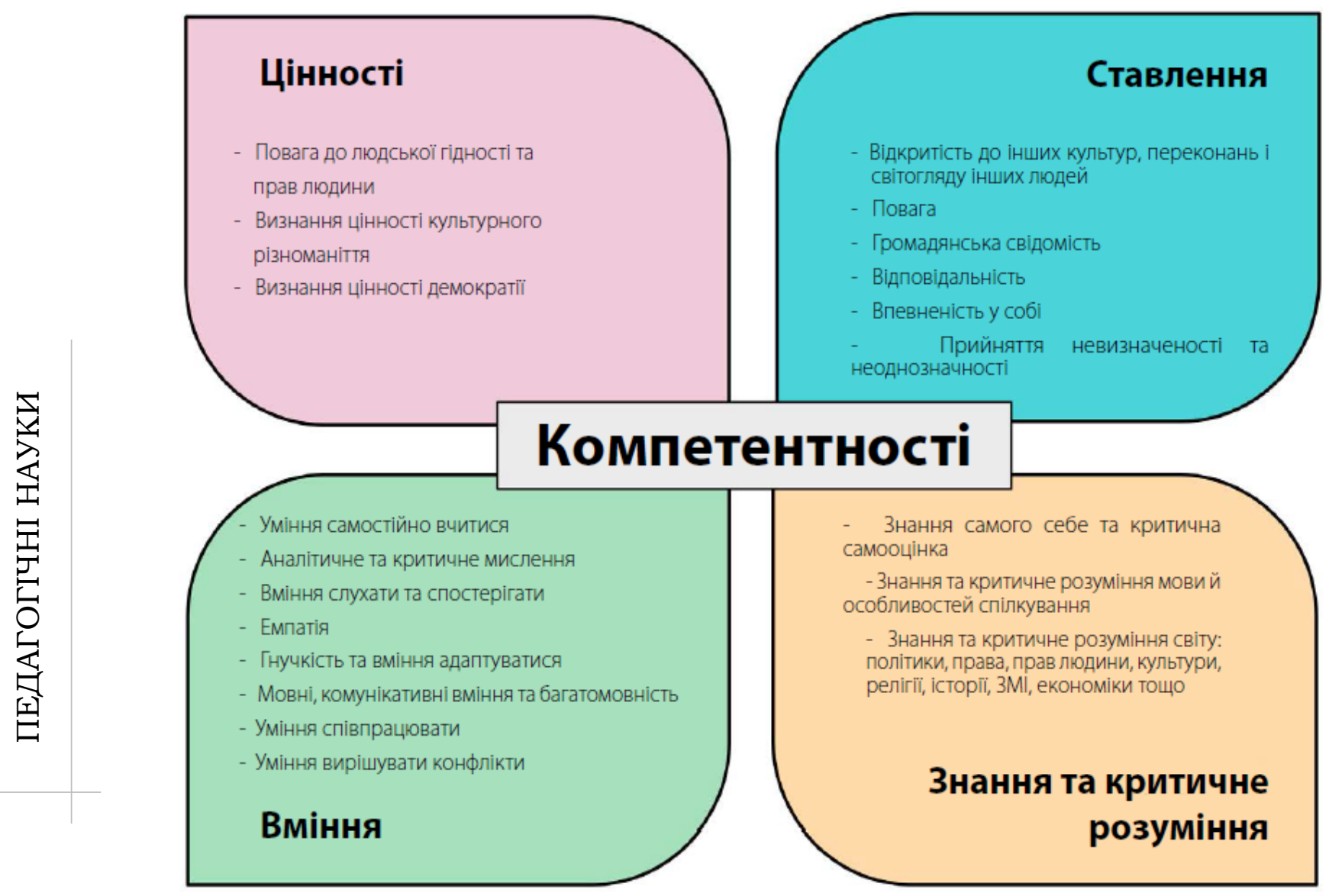

Рис. 1. Модель компетентностей “Культури демократії та міжкультурного діалогу” 
- інклюзї;

- обміну інформацією;

- піклування;

- заохочення;

- участі;

- чесності;

- самовираженню [3; 4].
На основі аналізу компетентностей культури демократії ми обрали п'ять головних компетентностей які будемо формувати у молодших школярів на ранкових зустрічах (див. табл. 1).

Для формування окремих компетентностей культури демократії, була розроблена система вправ (див. табл. 2).

\section{Головні компетентності для ранкових зустрічей}

Таблиця 1

\begin{tabular}{|c|c|c|}
\hline \multicolumn{3}{|c|}{ Повага до людської гідності та прав людини } \\
\hline 1. & Стверджуе, що права людини завжди слід поважати та захищати & Базовий \\
\hline 2. & Стверджує, що суспільство має поважати і захищати специфічні права дітей & Базовий \\
\hline 3. & $\begin{array}{l}\text { Відстоює думку про те, що ніхто не має зазнавати тортур або підлягати нелюдському чи } \\
\text { принизливому ставленню та покаранню }\end{array}$ & Високий \\
\hline 4. & $\begin{array}{l}\text { Аргументує, що всі державні установи повинні поважати, захищати права людини та } \\
\text { сприяти їх реалізації }\end{array}$ & Високий \\
\hline 5. & $\begin{array}{l}\text { Відстоює думку про те, що всі закони мають відповідати нормам і стандартам у галузі прав } \\
\text { людини }\end{array}$ & Високий \\
\hline \multicolumn{3}{|c|}{ Визнання цінності культурного різноманіття } \\
\hline 6. & $\begin{array}{l}\text { Дотримуеться поглядів, що ми маємо бути толерантними до різних переконань, яких } \\
\text { дотримуються інші люди у суспільстві }\end{array}$ & Високий \\
\hline 7. & $\begin{array}{l}\text { Дотримується поглядів, що кожен має докладати зусиль заради досягнення } \\
\text { взаєморозуміння та змістовного діалогу між людьми та групами, які різняться між собою }\end{array}$ & Високий \\
\hline 8. & $\begin{array}{l}\text { Стверджуе, що для того, щоб допомогти розпізнати наші різні ідентичності та культурну } \\
\text { належність, слід вести міжкультурний діалог }\end{array}$ & Високий \\
\hline \multicolumn{3}{|c|}{ Визнання цінності демократії, справедливості, рівності та верховенства права } \\
\hline 9. & $\begin{array}{l}\text { Підтримуе думку про те, що особи, яким довірена законодавча влада та її імплементація, } \\
\text { мають підлягати дії закону та конституційного нагляду }\end{array}$ & Високий \\
\hline 10. & $\begin{array}{l}\text { Висловлюе думку про те, що інформація про державну політику та її впровадження має } \\
\text { бути доступною для громадськості }\end{array}$ & Високий \\
\hline 11. & $\begin{array}{l}\text { Стверджуе, що мають існувати ефективні засоби правового захисту проти дій органів } \\
\text { державної влади, які порушують громадянські права. }\end{array}$ & Високий \\
\hline \multicolumn{3}{|c|}{ Громадянська свідомість. } \\
\hline 12. & Виявляе готовність взаємодіяти та працювати з іншими людьми. & Базовий \\
\hline 13. & Співпрацюе з іншими людьми заради спільних інтересів & Базовий \\
\hline 14. & Відчуває обов'язок не залишатися осторонь, коли порушують права та гідність інших & Середній \\
\hline 15. & Дискутуе про те, що можна зробити, аби змінити громаду на краще & Середній \\
\hline \multicolumn{3}{|c|}{ Уміння самостійно вчитися } \\
\hline 16. & $\begin{array}{l}\text { Виявляе здатність ідентифікувати ресурси для навчання (наприклад, людей, книги, } \\
\text { Інтернет тощо) }\end{array}$ & Базовий \\
\hline 17. & Може опанувати нові теми за мінімального стороннього супроводу & Середній \\
\hline 18. & Може оцінити якість виконання власної роботи & Середній \\
\hline 19. & $\begin{array}{l}\text { Виявляе здатність моніторити, визначати пріоритети та закінчувати завдання без } \\
\text { безпосереднього контролю }\end{array}$ & Високий \\
\hline
\end{tabular}

Система вправ для формування компетентностей культури демократії.

\begin{tabular}{|l|l|c|}
\hline \multicolumn{1}{|c|}{ Вправа } & \multicolumn{1}{|c|}{ Компетентність } & Рівень \\
\hline 1. Привітання & Визнання цінності культурного різноманіття & Базовий \\
\hline 2. Права, обов'язки та правила у класі & Повага до людської гідності та прав людини & Базовий \\
\hline 3. Філософія життя & Визнання цінності культурного різноманіття & Високий \\
\hline 4. Плакат з прав людини & $\begin{array}{l}\text { Визнання цінності демократії, справедливості, рівності та } \\
\text { верховенства права }\end{array}$ & Високий \\
\hline 5. Бажання та потреби & Уміння самостійно вчитися & Базовий \\
\hline 6. Усі різні, усі рівні & Громадянська свідомість & Базовий \\
\hline
\end{tabular}


При формуванні елементів культури демократії головну роль відіграє педагог, який володіє в досконалості сам знаннями і навичками по формуванню елементів культури в школярів. 3 цією метою було проведено анкетування вчителів, що здійснюють освітній процес в клаcax НУШ.

В період жовтня 2021 року було проведено анонімне анкетування вчителів початкового навчання малокомплектних сільських шкіл Чернігівського району. В ньому взяло участь 12 педагогів.

Опитування проводилося шляхом надання анкет. Анкетування вибіркове, заочне, індивідуальне, роздаточне, анонімне.

Мета анкетування: виявити ефективність впровадження реформи НУШ в частині проведення ранкових зустрічей та формування елементів культури демократії зокрема, ступінь підготовки вчителів до вироблення таких компетентностей.

\section{Запропонована анкета:}

Шановні вчителі, в межах нашого дослідження, просимо вас об'єктивно та анонімно дати відповіді на запитання "анкети"

1. Який клас Ви ведете?

A) 1-ий;

Б) 2-ий;

В) 3-ій;

Г) 4 -ий

2. Який Ваш досвід проведення Ранкових зустрічей?

А) початок проведення у цьому році;

Б) 1 рік;

В) 2 роки;

Г) 3 роки;

3. Які освітні завдання вирішують Ранкові зустрічі?

4. Що таке демократія?

5. Як пов'язані поняття “демократія" "освіта"?

6. Чи знайомі Ви з документом "Рамка компетентностей для культури демократії”?

A) $\mathrm{Hi}$, не чув (ла) про цей документ;

Б) Так, дещо чув(ла), але вивчати не доводилось;

В) Ознайомлений (на), проте не використовую у своїй практиці;

Г) Ознайомлений (на) та використовую у своїй практиці.

7. Які компетентності культури демократії необхідно, на Вашу думку, формувати у молодших школярів на заняттях у 1-2 класах?

А) Повага до людської гідності та прав людини; ніття;

Б) Визнання цінності культурного різнома-

В) Визнання цінності демократії, справедливості, рівності та верховенства права;

Г) Відкритість до інших культур, переконань і світогляду інших людей;

Д) Повага до людей;

Е) Відповідальність;

€) Впевненість у собі;

Ж) Уміння самостійно вчитися;

3) Аналітичне і критичне мислення;

I) Емпатія;
Й) Уміння співпрацювати;

К) Уміння вирішувати конфлікти;

Л) Знання самого себе та критична самооцінка;

М) Знання та критичне розуміння світу;

Н) Знання та критичне розуміння мови та особливостей спілкування;

O) Гнучкість та вміння адаптуватись;

П) Прийняття невизначеності та неоднозначності.

8. Які компетентності культури демократії необхідно, на Вашу думку, формувати у молодших школярів на заняттях у $3-4$ класах?

А) Повага до людської гідності та прав людини;

Б) Визнання цінності культурного різноманіття;

В) Визнання цінності демократії, справедливості, рівності та верховенства права;

Г) Відкритість до інших культур, переконань і світогляду інших людей;

Д) Повага до людей;

Е) Відповідальність;

€) Впевненість у собі;

Ж) Уміння самостійно вчитися;

3) Аналітичне і критичне мислення;

I) Емпатія;

И) Уміння співпрацювати;

К) Уміння вирішувати конфоікти;

Л) Знання самого себе та критична самооцінка;

М) Знання та критичне розуміння світу;

Н) Знання та критичне розуміння мови та особливостей спілкуванняя;

O) Гнучкість та вміння адаптуватись;

П) Прийняття невизначеності та неоднозначності.

9. Як на занятті можна реалізувати принцип "навчання через демократію”?

10. Як на занятті можна реалізувати принцип “навчання про демократію”?

11. "Як на занятті можна реалізувати принцип “навчання для демократії"?

12. Як часто Ви проводите Ранкові кола, на яких здійснюеться розвиток демократичних компетентностей?

А) Декілька разів на тиждень;

Б) Один раз на тиждень;

В) Один раз на два тижня;

Г) Один раз на місяць

13. Які чинники заважають частіше проводити Ранкові кола з формування елементів демократії?

А) необізнаність у цьому питанні;

Б) брак часу для підготовки спеціальних вправ та матеріалу;

В) відсутність навчально-методичної літератури з даного питання;

Г) вважаю, що розвиток демократичних цінностей у школярів має відбуватись у більш старшому віці.

14. Чи доцільною, на Вашу думку, буде розробка системи вправ та методичних рекомендацій для цілеспрямованого розвитку компетентностей культури демократії у молодших школярів?
А) так;

Б) нi. 
Результати обробки анкетування:

1. Діаграма № 1 показуе скільки педагогів працюе в тому, чи іншому класі НУШ

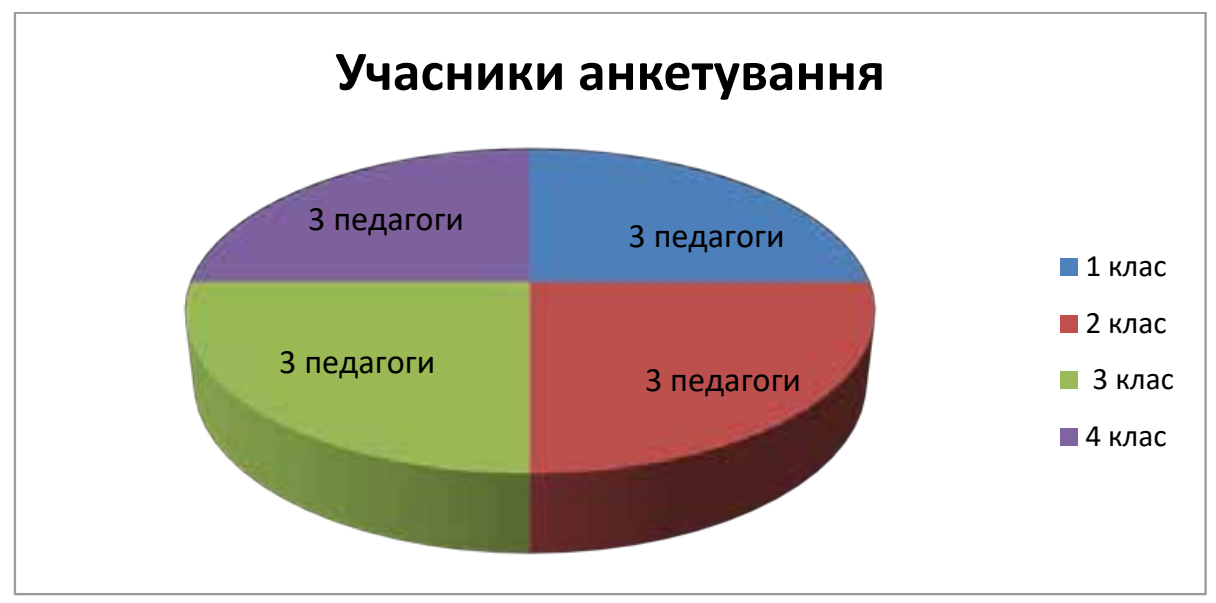

2. Діаграма № 2 показує досвід педагогів по проведенню Ранкових зустрічей в класах НУШ



3. Найбільш поширеними відповідями були:

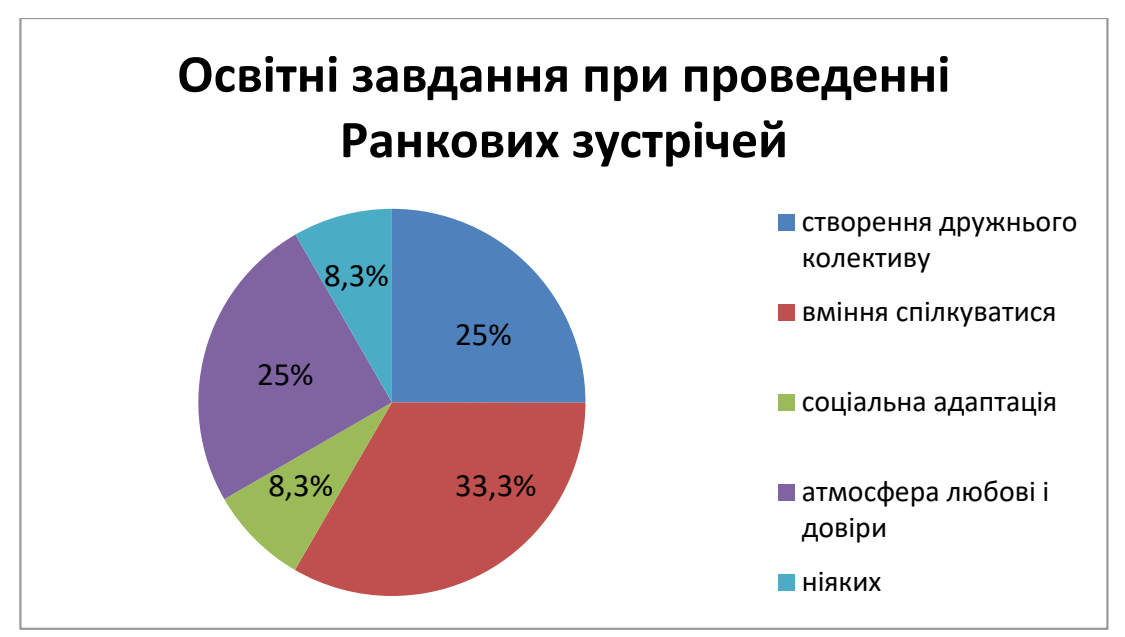


4. Правильна відповідь:

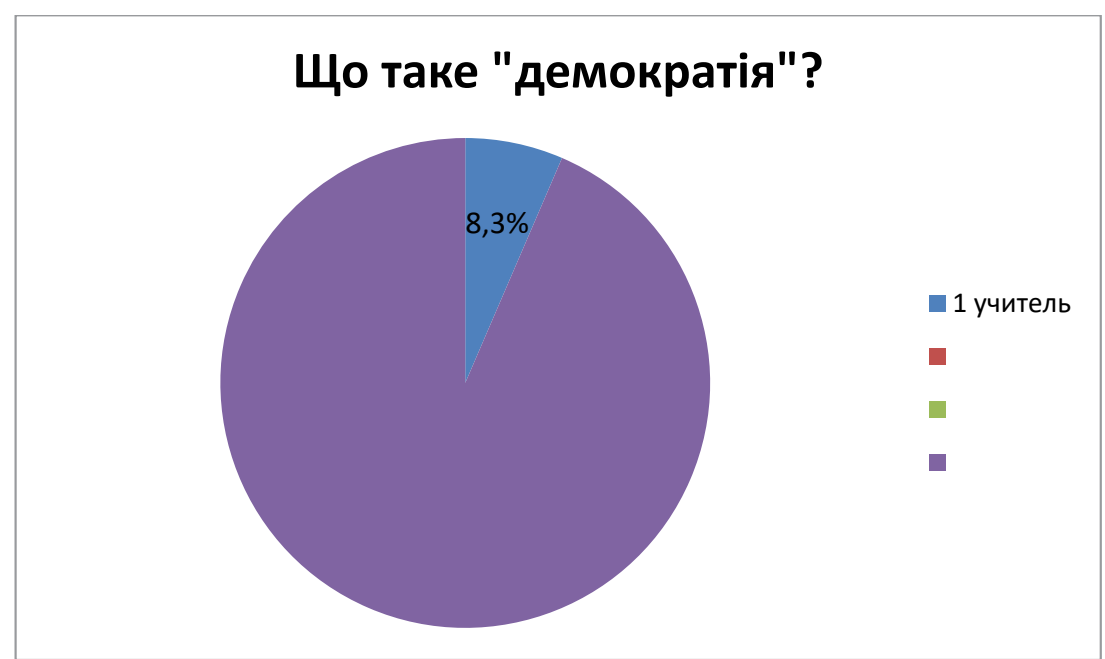

5. Як пов’язані поняття «демократія» $\mathrm{i}$ «освіта» показуе діаграма:

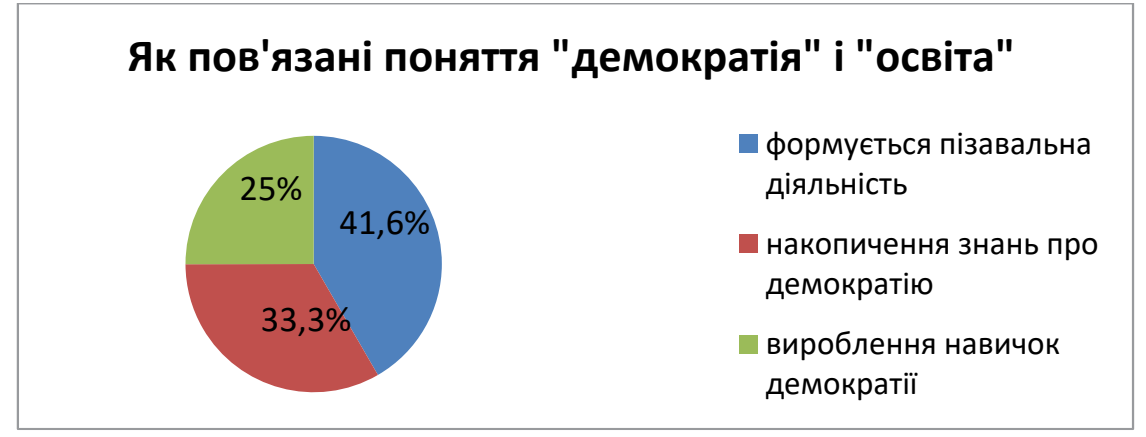

6. Діаграма № 6 демонструє знання вчителів про Рамку компетентностей для культури демократії:

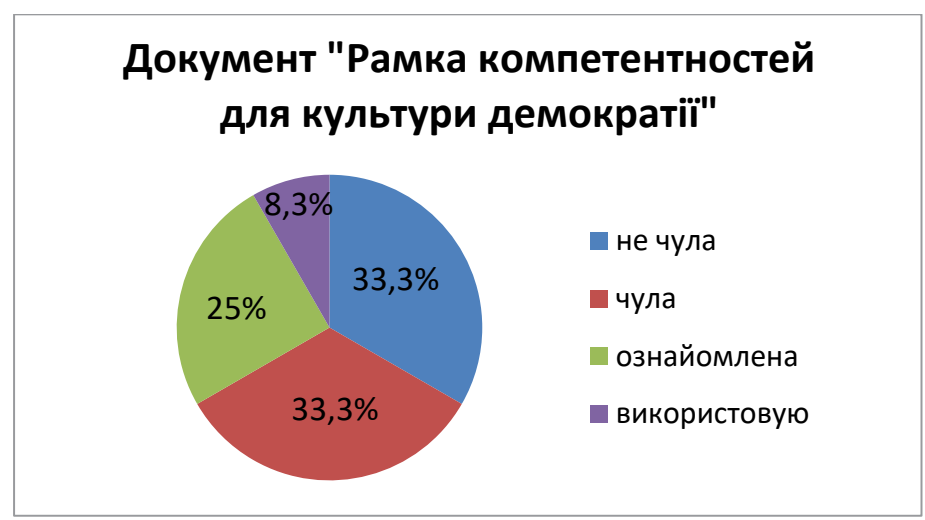

7. Переконання вчителів про поняття культури демократії, що доступні для учнів 1-2 класів простежуються на діаграмі:

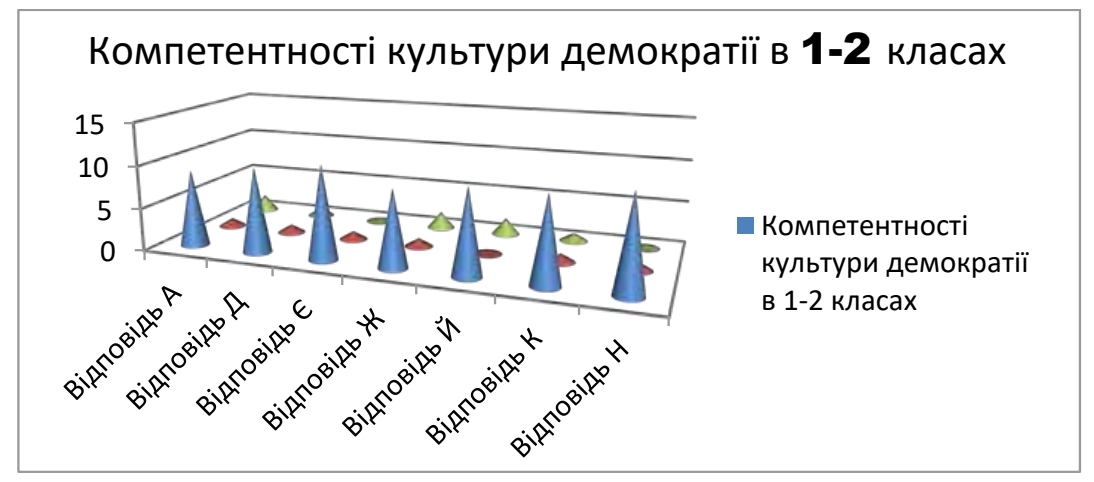


A - Повага до людської гідності та прав людини;

Д - Повага до людей;

Є - Впевненість у собі;

Ж - Уміння самостійно вчитися;
Й - Уміння співпрацювати;

К - Уміння вирішувати конфрлікти;

Н - Знання та критичне розуміння мови та особливостей спілкування;

8. Переконання вчителів про поняття культури демократії, що доступні для учнів 3-4 класів простежуються на діаграмі:



Б - Визнання цінності культурного різноманіття;

В - Визнання цінності демократії, справедливості, рівності та верховенства права;

Є- Відповідальність;
I - Емпатія;

К - Уміння вирішувати конфолікти;

Л - Знання самого себе та критична самооцінка; $\mathrm{O}$ - Гнучкість та вміння адаптуватись;

9. Принцип навчання «через демократію”? - заняття по залученню учнів до роботи в учнівському самоврядуванні класу, школи.

10. Принцип “навчання про демократію”? - заняття із ознайомленням прав і свобод дитини, людини.

11. Принцип “навчання для демократії”? - заняття на яких учні вчаться бути відповідальними за обіцяне, скоєне.

12. Діаграма демонструе частоту ранкових зустрічей по розвитку демократичних компетенцій:

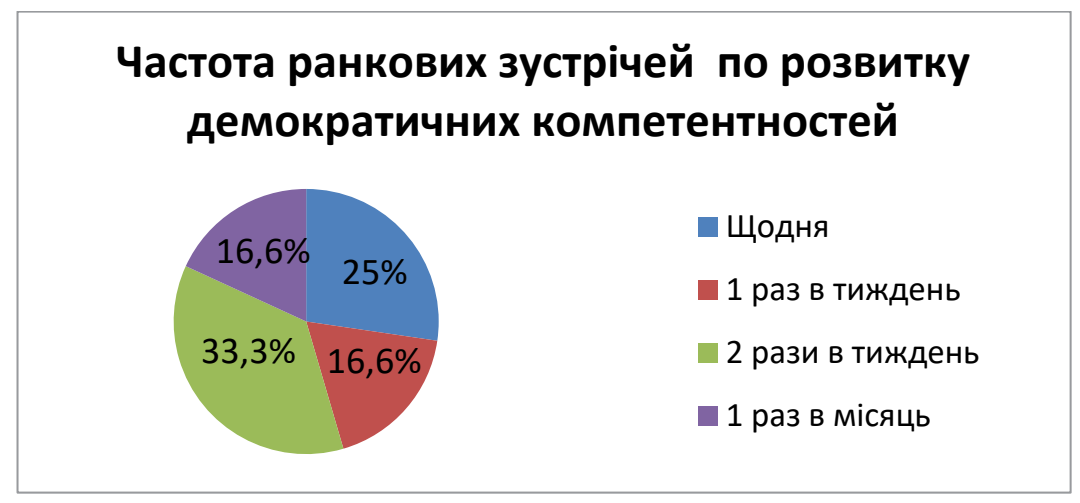


13. Причини невикористання елементів культури демократії:

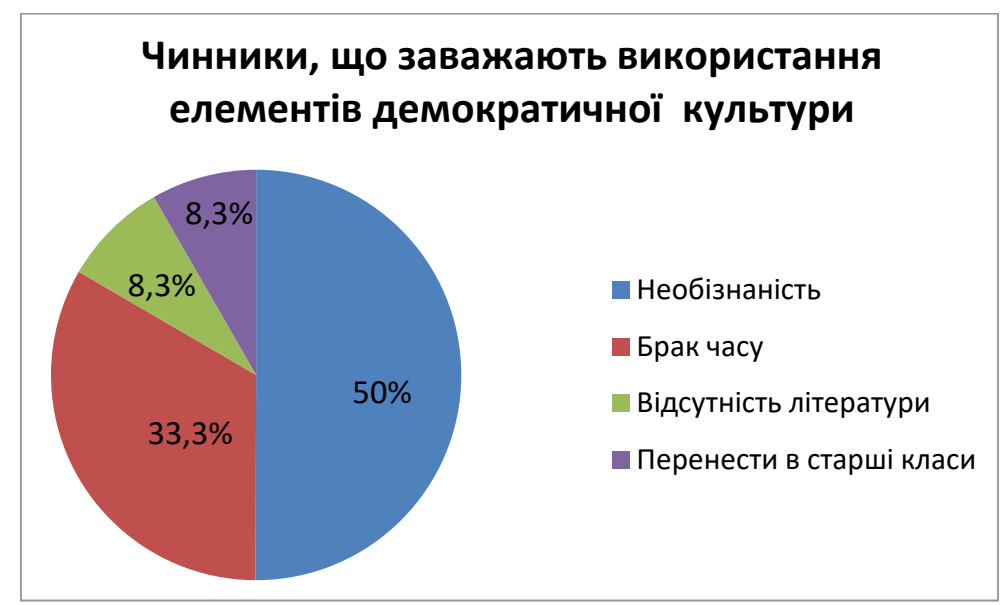

14. На запитання про дощільність розробки системи вправ та методичних рекомендацій щодо формування елементів демократичної культури при проведенні ранкових зустрічей: ТАК - відповіли $100 \%$ респондентів.

Висновки. Всі 12 респондентів мають різний стаж роботи в класах НУШ. Мають правильне уявлення про методику проведення ранкових зустрічей. Щодо формування елементів культури демократії під час проведення ранкових зустрічей, то вчителі показали, що цей напрямок роботи потребуе вдосконалення, бо:

- Вчителі слабо володіють поняттями «демократія» «держава» «фороми правління» і т.і.

- Не розуміють, як реалізувати принципи «навчання через демократію», «навчання про демократію», «навчання для демократії»

- Більшість вчителів не мають поняття про Рамку компетентностей для культури демократії, розроблену Радою Свропи.

- Самі компетентності часто вживають, але не знають, що вони складають Рамку.

- Недостатньо розробок з матеріалами формування елементів культури демократії під час проведення ранкових зустрічей.
- Більшість вчителів вважають вироблення компетентностей елементів культури демократії під час проведення ранкових зустрічей слід перенести в старшу ланку.

Отже, фрормування елементів культури демократії молодших школярів є необхідною умовою при запровадженні освітньої реформи НУШ. Ранкові зустрічі - нова активна педагогічна технологія, яка дає дітям змогу брати участь у групових обговореннях, а педагогам - моделювати й активно розвивати в дітей уміння та навички ефрективного спілкування. Щодо вироблення компетенщій елементів культури демократії, то ці навички сприяють розвитку відчуття спільноти і ширший діапазон позитивних проявів таких якостей як краще ставлення до школи й навчання, більша довіра та повага до вчителя, вищий рівень мотивації до навчання, глибше відчуття власної гідності, збільшення турботи про інших, повніше розуміння демократичних цінностей, ширша практика розв'язання кондрліктів.

\section{Список літератури:}

1. Council of Europe (2018a). Reference Framework of Competences for Democratic Culture. Context, concepts and model. Strasbourg: Council of Europe Publishing. Vol. 1. P. 83.

2. Council of Europe (2018b). Reference Framework of Competences for Democratic Culture. Descriptors of competences for democratic culture. Strasbourg: Council of Europe Publishing. Vol. 2. P. 65.

3. Сідлецький А. Ранкові зустрічі. Початкова школа. 2013. № 10. С. 33-36.

4. Скрипещ М.В. Ранкові зустрічі як засіб розвитку учнівської особистості: навчання і виховання за програмою «Крок за кроком». Початкове навчання та виховання : наук.-метод. журн. Харків : Вид. група «Основа», 2007. № 9. С. $2-6$.

5. Голлоб Р., Крапф П. Пер. з англ. та адапт. Н. Г. Протасової. Навчання демократії: збірник практичних занять з освіти для демократичного громадянства та освіти з прав людини. Київ : Основа, 2016. Т. 6.100 с.

\section{References:}

1. Council of Europe (2018a) Reference Framework of Competences for Democratic Culture. Context, concepts and model. Strasbourg: Council of Europe Publishing, vol. 1, p. 83.

2. Council of Europe (2018b) Reference Framework of Competences for Democratic Culture. Descriptors of competences for democratic culture. Strasbourg: Council of Europe Publishing, vol. 2, p. 65.

3. Sidletsky A. (2013) Rankovi zustrichi [Morning meetings]. Pochatkova shkola, vol. 10, pp. 33-36.

4. Skrypets M.V. (2007) Rankovi zustrichi yak zasib rozvytku uchnivskoi osobystosti: navchannya i vyhovannya za programoyu "Krok za krokom" [Morning meetings as a means of developing pupils' personality: training and education in the program "Krok za krokom"]. Pochatkove navchannya ta vyhovannya: nauk.-metod. zhurn. Kharkiv: Vyd. Hrupa "Osnova", vol. 9, pp. 2-6.

5. Gollob R., Krapf P. (2016) Navchannya demokratii: zbirnyk praktychykh zanyat z osvity dlya demokratychnogo hromadyanstva ta osvity z pram lyudyny [Teaching democracy: a collection of practical lessons on education for democratic citizenship and human rights education]. Kyiv: Osnova, vol. 6, p. 100. 